\title{
UTILIZATION OF LOW NOx COAL COMBUSTION BY-PRODUCTS
}

First Quarterly Report: April 23, 1998 through June 30, 1998

\author{
Authored by: \\ J.Y. Hwang, X. Huang, and A.M. Hein
}

August 1998

DE-FC26-98FT40324--01

\author{
Institute of Materials Processing \\ Michigan Technological University \\ 1400 Townsend Drive \\ Houghton, MI 49931-1295
}

\begin{abstract}
Disclaimer
This report was prepared as an account of work sponsored by an agency of the United States Government. Neither the United States Government nor any agency thereof, nor any of their employees, makes any warranty, express or implied, or assumes any legal liability or responsibility for the accuracy, completeness, or usefulness of any information, apparatus, product, or process disclosed, or represents that its use would not infringe privately owned rights. Reference herein to any specific commercial product, process, or service by trade name, trademark, manufacturer, or otherwise does not necessarily constitute or imply its endorsement, recommendation, or favoring by the United States Government or any agency thereof. The views and opinions of authors expressed herein do not necessarily state or reflect those of the United States Government or any agency thereof.
\end{abstract}




\section{UTILIZATION OF LOW NOx COAL COMBUSTION BY-PRODUCTS DE-FC26-98FT40324}

First Quarterly Report: April 23, 1998 through June 30, 1998

\section{TABLE OF CONTENTS}

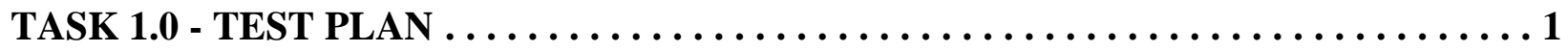

TASK 2.0 - LABORATORY CHARACTERIZATION $\ldots \ldots \ldots \ldots \ldots \ldots \ldots \ldots \ldots \ldots \ldots 1$

Task 2.1 - Sample Collection $\ldots \ldots \ldots \ldots \ldots \ldots \ldots \ldots \ldots \ldots \ldots \ldots \ldots \ldots \ldots$

Task 2.2 - Material Characterization $\ldots \ldots \ldots \ldots \ldots \ldots \ldots \ldots \ldots \ldots \ldots \ldots$

Task 2.3 - Laboratory Testing of Ash Processing Operations $\ldots \ldots \ldots \ldots \ldots \ldots$

TASK 3.0 - PILOT PLANT TESTING $\ldots \ldots \ldots \ldots \ldots \ldots \ldots \ldots \ldots \ldots \ldots \ldots$

TASK 4.0 - PRODUCT TESTING $\ldots \ldots \ldots \ldots \ldots \ldots \ldots \ldots \ldots \ldots \ldots \ldots \ldots \ldots \ldots$

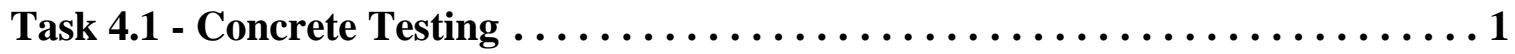

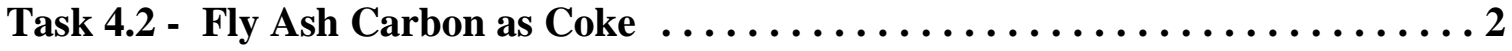

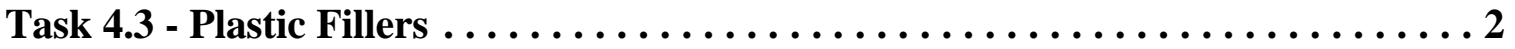

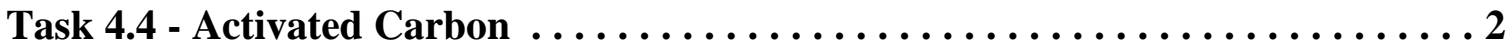

Task 4.5 - Additive for Powder-Based Aluminum Composites $\ldots \ldots \ldots \ldots \ldots$.

APPENDIX A: Task 1.0 - Test Plan: PROJECT TEST PLAN $\ldots \ldots \ldots \ldots \ldots \ldots \ldots$. 


\section{UTILIZATION OF LOW NOx COAL COMBUSTION BY-PRODUCTS DE-FC26-98FT40324}

\section{First Quarterly Report: April 23, 1998 through June 30, 1998}

TASK 1.0 - TEST PLAN

The project test plan is attached in Appendix A.

\section{TASK 2.0 - LABORATORY CHARACTERIZATION}

\section{Task 2.1 - Sample Collection}

Fly ash samples were received from Potomic Electric Power (Pepco), Western Massachusetts Electric Power, Virginia Electric Power, and United Illuminating.

Task 2.2 - Material Characterization This task was not underway in the first quarter.

Task 2.3 - Laboratory Testing of Ash Processing Operations This task was not underway in the first quarter.

\section{TASK 3.0 - PILOT PLANT TESTING}

This task was not underway in the first quarter.

\section{TASK 4.0 - PRODUCT TESTING}

Plastic fillers and powder-based aluminum composites typically use fly ash with a particle size of less than five microns. Clean ash classification generates a fine fraction, $\sim 5$ microns, and a coarse fraction, $\sim 30$ microns. There is a need to find additional uses for the coarser size fraction. Concrete is one area being studied in this project. Other possible applications in which a 30micron ceramic particle with good flowability is desired include ceramic slurries for investment casting, ceramic coatings for metal casting sand molds, and for use as a surfacing sand. If more information is obtained about these or other applications, it may be included in these reports.

Task 4.1 - Concrete Testing This task was not underway in the first quarter. 
Task 4.2 - Fly Ash Carbon as Coke Formcoke has an advantage in that it uses lower grade coal to produce high quality metallurgical coke. Residual carbon separated from fly ash during beneficiation is a potential raw material to produce formcoke. A literature search has been conducted and review of the information is underway.

Task 4.3 - Plastic Fillers In previous projects, IMP has tested fine clean ash as a filler in PVC, polypropylene, low density polyethylene, and high density polyethylene and concluded that fine clean ash can replace commercial $\mathrm{CaCO}_{3}$ filler in these polymer systems. IMP has also attracted an initial interest from a polymer compounder, Vi-Chem Corporation, for commercial use of the ash as a filler.

One objective of this task is to test the fine clean ash filler in more polymer systems. A second objective is to promote commercial use, which is being done in conjunction with Vi-Chem and Mineral Resource Technologies (MRT). A third objective of this task is to evaluate the effect of residual flotation reagents on clean ash surfaces to determine if there are any impacts on the mechanical properties of the filled polymers.

During this quarter, the decision was made to test nylon, ABS, and polycarbonate. These polymers were obtained.

A sample of fine clean ash was sent to Vi-Chem for them to test as a filler in commercial PVC compounds and compare the results with commercial $\mathrm{CaCO}_{3}$ and feldspar fillers. The results were very promising. A meeting was held at the Vi-Chem offices in Grand Rapids, Michigan on April 30, 1998 to further discuss these activities.

Task 4.4 - Activated Carbon This task was not underway in the first quarter.

Task 4.5 - Additive for Powder-Based Aluminum Composites This task was not underway in the first quarter. 


\section{APPENDIX A}

Task 1.0 - Test Plan

PROJECT TEST PLAN

Utilization of Low NOx Coal Combustion By-Products DE-FC26-98FT40324

First Quarterly Report (Apr-Jun 1998)
Institute of Materials Processing Michigan Technological University August 1998 


\section{UTILIZATION OF LOW NOx COAL COMBUSTION BY-PRODUCTS \\ DE-FC26-98FT40324 \\ PROJECT TEST PLAN}

\section{TASK 2.0 - LABORATORY CHARACTERIZATION}

\section{Task 2.1 - Sample Collection}

Large samples of fly ash from four generating plants will be obtained.

\section{Task 2.2 - Material Characterization}

All samples will be characterized to determine physical and chemical properties of the asreceived and clean fly ash.

\section{Task 2.3 - Laboratory Testing of Ash Processing Operations}

Laboratory testing includes flowsheet confirmation, evaluation of environmentally friendly reagents, and upgrading the carbon concentrate.

\section{TASK 3.0 - PILOT PLANT TESTING}

Pilot scale testing will be conducted to verify that the process is flexible and consistent, and widely applicable in commercial applications. Samples will be generated for additional testing and data for engineering design will be collected.

\section{TASK 4.0 - PRODUCT TESTING}

\section{Task 4.1 - Concrete Testing}

Tests will be run on cleaned fly ash samples to determine if flotation reagents are causing the strength of the concrete to be lower than desired.

\section{Task 4.2 - Fly Ash Carbon as Coke}

Fly ash carbon will be characterized to determine if it meets chemical and physical specifications for coke. Tests will be conducted to determine if the fly ash coke meets performance requirements for the iron and steel industry. 


\section{Task 4.3 - Plastic Fillers}

Fly ash will be tested as a filler in selected polymers. The effect of particle size and other parameters will also be tested.

\section{Task 4.4 - Activated Carbon}

Fly ash carbon will be tested for suitability in waste water and air emission pollution control applications.

\section{Task 4.5 - Additive for Powder-Based Aluminum Composites}

Powder-metallurgy-based aluminum- 30 vol\% fly ash composite test coupons will be fabricated and then evaluated using a combination of tensile, wear, and machinability testing. Asreceived and clean fly ash will be tested. A selectively-reinforced aluminum casting will be produced and evaluated to assess the effectiveness of a cast-in-place operation. 